\title{
Announcing the new launch of The Egyptian Journal of Neurology, Psychiatry and Neurosurgery
}

\section{Ossama Abdulghani, Ahmed M. Abdelalim and Khaled O. Abdulghani*}

We are honored to announce the new launch of the Egyptian Journal of Neurology, Psychiatry and Neurosurgery (EJNPN), the official publication of the Egyptian Society of Neurology, Psychiatry and Neurosurgery (ESNPN), a peer-reviewed, open access journal publishing articles in the field of clinical neurosciences, including neurology, psychiatry and neurosurgery. The journal presents cutting edge research on clinical, technical, ethical and social aspects of clinical neurosciences.

First, we must acknowledge our colleagues who are joining us in the editorial office currently in Cairo, Egypt. They represent the true motivators and dynamos for the journal. Leading the scientific publication in the neurosciences field in Egypt, the Middle East and North Africa; the EJNPN was first published in 1960. Throughout the years, the journal has been indexed by several indexing services, including EMBASE and Scimago journal ranking. At the meantime, we are working closely with other relevant indexing services including PubMed Central and Web of Science to ensure that articles published in the EJNPN will be available in their databases when appropriate.

Taking the next step towards better indexing, ranking, reader's exposure and targeting more authors from around the world, the journal moved to Springer Open - Springer Nature, through an agreement with the Egyptian Knowledge Bank as an open access and free-of-charge journal. Open access allows the journal to reach a larger set of authors and readers (Suber 2005) with higher downloads and citations, leading to a higher Impact Factor (Hitchcock n.d.; Brody and Harnad n.d.). This also helps avoiding any influence of the economy on the reader's ability to access articles (Tan-Torres Edejer 2000).

Authors hold copyright for their work and grant anyone the right to reproduce and disseminate the article, provided that it is correctly cited. This complies with the

* Correspondence: Khaled.abdulghani@med.helwan.edu.eg Helwan University School of Medicine, Cairo, Egypt policies of several funding bodies including the Wellcome Trust, NIH and Howard Hughes Medical Institute (Janka5 2018; Janka6 2018; Janka7 2018; Janka8 2018).

The EJNPN operates a double-blind peer-review system, where the reviewers do not know the names or affiliations of the authors and the reviewer reports provided to the authors are anonymous. Submitted manuscripts will generally be reviewed by two to three experts who will be asked to evaluate whether the manuscript is scientifically and ethically sound and coherent, whether it duplicates already published work, and whether or not the manuscript is sufficiently clear for publication. Reviewers will also be asked to indicate how interesting and significant the research is. The Editors will reach a decision based on these reports, and where necessary, they will consult with members of the Editorial Board (Janka9 2018). Articles will be published online soon upon acceptance and hopefully soon, after being listed, in PubMed Central/PubMed.

We welcome your research and scientific work to be submitted to the EJNPN (Janka10 2018). We promise you visibility, flexibility and speedy publication, together with better promotion and press coverage.

M. Ossama Abdulghani-The Editor-in-Chief, EJNPN.

Ahmed M. Abdelalim and Khaled O. AbdulghaniThe Associate Editors, EJNPN.

Authors' contributions

All authors read and approved the final manuscript.

\section{Authors' information}

M. Ossama Abdulghani is the Editor-in-Chief of this journal. Ahmed M. Abdelalim and Khaled O. Abdulghani are Associate Editors of the journal.

Competing interests

All authors declare that they have no competing interests.

\section{Publisher's Note}

Springer Nature remains neutral with regard to jurisdictional claims in published maps and institutional affiliations. 
Received: 21 March 2018 Accepted: 23 March 2018

Published online: 25 April 2018

\section{References}

Brody T, Harnad S. Earlier web usage statistics as predictors of later citation impact: http://eprints.ecs.soton.ac.uk/10713/02/timcorr.htm. Accessed Mar 2018.

Hitchcock: The effect of open access and downloads ('hits') on citation impact: a bibliography of studies: http://opcit.eprints.org/oacitation-biblio.html. Accessed Mar 2018.

Janka10 2018 The Egyptian Journal of Neurology, Psychiatry and Neurosurgery-Editorial manager and submission system https://www. editorialmanager.com/ejnp/. Accessed Mar 2018.

Janka5 2018 Which funding agencies explicitly allow direct use of their grants to cover article processing charges?: https://www.springernature.com/gp/openresearch/funding. Accessed Mar 2018.

Janka6 $2018 \mathrm{NIH}$ calls on scientists to speed public release of research publications: https://grants.nih.gov/grants/oer.htm. Accessed Mar 2018

Janka7 2018 Wellcome Trust position statement in support of open and unrestricted access to published research: http://www.wellcome.ac.uk/ node3302.html. Accessed Mar 2018.

Janka8 2018 Howard Hughes Medical Institute Research Policies_public access publishing http://www.hhmi.org/about/research/sc320.pdf. Accessed Mar 2018.

Janka9 2018 The Egyptian Journal of Neurology, Psychiatry and Neurosurgery—Editorial Board https://ejnpn.springeropen.com/about/ editorial-board. Accessed Mar 2018.

Suber P. Open access, impact, and demand. BMJ. 2005;330:1097.

Tan-Torres Edejer T. Disseminating health information in developing countries: the role of the internet. BMJ. 2000;321:797-800. http://bmj.bmjjournals.com/ cgi/content/full/321/7264/797

\section{Submit your manuscript to a SpringerOpen ${ }^{\odot}$ journal and benefit from:}

- Convenient online submission

- Rigorous peer review

- Open access: articles freely available online

- High visibility within the field

- Retaining the copyright to your article

Submit your next manuscript at $\gg$ springeropen.com 